\title{
ANALISIS PENGARUH KETERLIBATAN KERJA DAN KEPUASAN KERJA TERHADAP ORGANIZATIONAL CITIZENSHIP BEHAVIOR DI PT PRIMA GRAPHIA DIGITAL
}

\author{
Andrew Adi Saputra; Liemdra Hendro Yono; Laksmi Sito Dwi Irvianti \\ Management Department, School of Business Management, BINUS University \\ Jln. K. H. Syahdan No. 9, Palmerah, Jakarta Barat 11480 \\ andrewadisaputra@yahoo.co.id; liemdrahendroyono@yahoo.co.id; laksmisito@yahoo.com
}

\begin{abstract}
PT Prima Graphia Digital is a company engaged in the area of digital printing, locates at Kalibaru Timur Street IV No 5-7, Senen, Central Jakarta, Indonesia, 10460. The purpose of this research is to analyze the effect of job involvement and work satisfaction towards Organizational Citizenship Behavior in PT. Prima Graphia Digital. Research used associative method. Data used were primary and secondary data obtained through observation, interview and questionnaire distribution to 86 staffs of the company as respondents. After obtaining the data, then data were processed using Pearson correlation, simple and multiple regression. Results showed that job involvement has positive effect and is significant towards Organizational Citizenship Behavior. Similarly, work satisfaction does also have a positive effect and is significant towards Organizational Citizenship Behavior. Furthermore, job involvement and work satisfaction simultaneously have a significant effect towards Organizational Citizenship Behavior.
\end{abstract}

Keywords: job involvement, work satisfaction, Organizational Citizenship Behavior

\begin{abstract}
ABSTRAK
PT Prima Graphia Digital merupakan perusahaan yang bergerak di bidang digital printing, berlokasi di Jln. Kalibaru Timur IV No.5-7, Senen, Jakarta Pusat - Indonesia 10460. Tujuan dari penelitian ini adalah untuk menganalisis pengaruh Keterlibatan Kerja dan Kepuasan Kerja terhadap Organizational Citizenship Behavior di PT Prima Graphia Digital. Penelitian menggunakan metode asosiatif dengan data primer dan sekunder yang diperoleh melalui observasi, wawancara, dan kuesioner kepada 86 orang karyawan sebagai responden. Dari data yang diperoleh, kemudian dianalisis dengan menggunakan korelasi pearson, regresi sederhana, dan regresi berganda. Dari hasil penelitian diperoleh bahwa Keterlibatan Kerja memiliki pengaruh yang positif dan signifikan terhadap Organizational Citizenship Behavior, Kepuasan Kerja juga memiliki pengaruh yang positif dan signifikan terhadap Organizational Citizenship Behavior. Begitu juga dengan Keterlibatan Kerja dan Kepuasan Kerja secara silmutan memiliki pengaruh yang signifikan terhadap Organizational Citizenship Behavior.
\end{abstract}

Kata kunci: keterlibatan kerja, kepuasan kerja, Organizational Citizenship Behavior. 


\section{PENDAHULUAN}

PT Prima Graphia Digital merupakan suatu perusahaan yang bergerak di bidang printing yang berdiri sejak tahun 2002 sampai saat ini. PT. Prima Graphia Digital telah berhasil membangun bisnisnya dengan baik dengan integritas yang tinggi serta kecepatan dan kreativitas yang tinggi. Namun infrastuktur saja tentu tidak cukup menjaga perusahaan tetap kompetitif di antara banyak pesaing. Seperti yang diketahui bahwa sebagai perusahaan yang bergerak di bidang printing sangat membutuhkan sumber daya manusia karena sumber daya itu merupakan suatu aset yang tidak bisa tergantikan dalam mencapai tujuan dan keberhasilan perusahaan. Oleh karena itu, setiap perusahaan bukan saja mengaharapkan karyawan yang berkinerja baik tetapi juga membutuhkan karyawan yang dapat memberikan kontribusi ekstra (extra-role). Kontribusi ekstra yang dimaksud yaitu ketika karyawan dapat memberikan dan mengahabiskan waktunya untuk bekerja di dalam perusahaan melebihi yang diwajibkan dari perusahaan. Perilaku kontribusi ekstra (extra-role) ini disebut dengan kewargaan organisasional (Organizational Citizenship Behavior/OCB). Karyawan yang memiliki OCB tentunya memberikan kontribusi melebihi yang diharapkan oleh perusahaan. Jika seseorang karyawan tidak menunjukan perilaku extra-role, pastinya karyawan tersebut tidak mengindikasikan terciptanya OCB pada diri mereka. OCB sendiri berkaitan dengan kepuasan kerja karena jika karyawan merasa puas, berkemungkinan lebih besar dirinya untuk berbicara secara positif tentang organisasi, membantu rekan kerja, dan membuat kinerja mereka melebihi perkiraan normal. Sedangkan kepuasan kerja dapat dilihat dari keterlibatan kerja karyawan yang dikaitkan dengan tingkat kemangkiran dan tingkat permohonan berhenti. Setelah menindaklanjuti permasalahan yang ada, penelitian melakukan wawancara dengan beberapa karyawan di PT Prima Graphia Digital dapat disimpulkan bahwa OCB tersebut sudah diterapkan karyawan PT Prima Graphia Digital. Akan tetapi, OCB yang diterapkan karyawan tersebut belum berjalan secara efektif karena masih banyak karyawan yang tidak bersedia untuk bekerja lembur dengan kata lainnya conscientiousness. Selain itu para karyawan juga belum memiliki sikap untuk saling membantu rekan kerja mereka yang memerlukan bantuan atau dengan kata lainnya altruism. Sedangkan di dalam sistem kepuasan kerja masih ada kekurangan prosedur dalam perusahaan karena lambatnya respons yang diberikan perusahaan tersebut kepada karyawan yang membutuhkan. Sebagai contoh adalah lambatnya proses permintaan alat tulis kantor di perusahaan tersebut sehingga menghambat kinerja para karyawan. Untuk masalah dalam keterlibatan kerja masih adanya karyawan yang memiliki tingkat absensi yang tinggi. Contohnya masih banyak keterlambatan karyawan di dalam perusahaan tersebut sehingga hal ini mengakibatkan kinerja karyawan kurang maksimal terhadap kinerja individu masing-masing.

Dari latar belakang, dapat diidentifikasikan beberapa masalah, yaitu apakah ada pengaruh antara keterlibatan kerja (X1) dan kepuasan kerja (X2) terhadap Organizational Citizenship Behavior (Y) baik secara parsial maupun simultan. Sedangkan tujuan penelitian adalah untuk mengetahui jika ada pengaruh antara keterlibatan kerja (X1) dan kepuasan kerja (X2) terhadap Organizational Citizenship Behavior (Y) secara parsial dan simultan.

\section{Kajian Pustaka}

Lodahl dan Kejner dalam Liao dan Lee (2009) mendefinisikan keterlibatan kerja adalah tentang cara seseorang mencerminkan dan menganggap bahwa pekerjaannya merupakan hal yang penting atau utama. Selain itu keterlibatan kerja juga merupakan sejauh mana seseorang karyawan terlibat dalam pekerjaannya. Menurut Robbins dan Coulter (2007) mengatakan bahwa keterlibatan kerja adalah tingkat pengindenfikasian psikologis karyawan dengan perkerjaannya, secara aktif berpartisipasi dalam pekerjaannya, dan menganggap kinerjanya di pekerjaannya adalah penting untuk kebaikan dirinya sendiri. Sehingga dapat disimpulkan bahwa karyawan yang memiliki keterlibatan kerja yang tinggi, karyawan tersebut akan benar-benar serius menangani pekerjaannya dengan 
demikian dapat mengurangi absensinya, dan dari tingkat pengunduran diri. Sebaliknya jika karyawan yang kurang terlibat dalam pekerjaannya, karyawan tersebut hanya bekerja secara rutinitas.

Menurut Lodahl dan Kejner dalam Millmore (2007:204), keterlibatan kerja memiliki dua dimensi. Pertama, performace, self-esteem, contingency, keterlibatan kerja merefleksikan tingkat yang rasa harga diri karyawan dipengaruhi oleh performance kerja. Aspek ini mencakup tentang seberapa jauh hasil kerja seorang karyawan (performance) dapat memengaruhi harga dirinya (self-esteem). Keterlibatan kerja muncul ketika ada kemungkinan (contingency) performance yang baik sehingga meningkatkan harga diri seseorang. Kedua, pentingnya pekerjaan bagi gambaran total individu, dimensi ini merujuk pada tingkat sejauh mana karyawan mengidentifikasikan diri secara psikologis pada pekerjaan atau pentingnya pekerjaan bagi gambaran diri secara total. Dubin (Istijanto, 2005) mengatakan bahwa karyawan yang memiliki keterlibatan kerja adalah karyawan yang menganggap pekerjaan sebagai bagian yang paling penting dalam hidupnya. Ini berarti bahwa dengan bekerja, karyawan dapat mengekspresikan diri dan menganggap bahwa pekerjaan merupakan aktivitas yang menjadi pusat kehidupan. Menurut Robbins (2008), karyawan yang memiliki tingkat keterlibatan yang tinggi sangat berpihak dan benar-benar peduli dengan bidang pekerjaan yang mereka lakukan.

Menurut pendapat Robbins (2003), kepuasan kerja adalah salah satu sikap umum terhadap pekerjaan seseorang, selisih antara banyaknya ganjaran yang diterima seseorang pekerja dan banyaknya yang mereka yakini seharusnya mereka terima. Menurut Luthans (2006), kepuasan kerja adalah hasil dari persepsi karyawan mengenai seberapa baik pekerjaan mereka memberikan hal yang dinilai penting. Sedangkan menurut Mathis dan Jackson (2006), kepuasan kerja adalah keadaan emosional yang merupakan hasil dari evaluasi pengalaman kerja seseorang.

Menurut Luthans (2006), ada beberapa faktor penentu kepuasan kerja karyawan dalam perusahaan, yaitu sebagai berikut. Pertama, pekerjaan. Kepuasan terhadap pekerjaan merupakan sumber utama kepuasan, yang di dalamnya perkerjaan memberikan tugas yang menarik, kesempatan untuk belajar, dan kesempatan untuk menerima tanggung jawab. Berdasarkan survei diagnostik pekerjaan, diperoleh hasil tentang 5 ciri yang memerhatikan kaitannya dengan kepuasan kerja untuk berbagai macam pekerjaan, yaitu: (a) keragaman keterampilan, banyak ragam keterampilan yang diperlukan untuk melakukan pekerjaaan; makin banyak ragam keterampilan yang digunakan, maka makin kurang membosankan perkerjaan, (b) jati diri tugas (task indentity), sejauh mana tugas merupakan suatu kegiatan keseluruhan yang berarti; (c) tugas yang penting (task significance), rasa pentingnya tugas bagi seseorang. Jika tugas yang dirasakan penting dan berarti oleh tenaga kerja, ia cenderung mempunyai kepuasan kerja; (d) pemberian umpan balik (feedback) pada perkerjaan membantu meningkatkan tingkat kepuasan kerja. Kedua, gaji/imbalan yang dirasakan adil. Dengan menggunakan teori keadilan Adams, orang menerima gaji yang dipersepsikan sebagai terlalu kecil atau terlalu besar akan mengalami distress (ketidakpuasan), sehingga gaji itu harus diberikan secara adil berdasarkan hasil kerja yang diberikan oleh karyawan. Ketiga, kesempatan promosi. Menyangkut kemungkinan seseorang untuk maju dalam organisasi dan dapat berkembang melalui kenaikan jabatan. Seseorang dapat merasakan adanya kemungkinan yang besar untuk naik jabatan atau tidak, serta proses kenaikan jabatan terbuka atau kurang terbuka. Hal ini juga akan memengaruhi tingkat kepuasan kerja seseorang. Keempat, pengawasan. Atasan yang senantiasa memberikan perintah atau petunjuk dalam pelaksanaan kerja. Cara-cara atasan dalam meperlakukan bawahannya dapat menjadi menyenangkan atau tidak menyenangkan bagi bawahannya tersebut; dan hal ini memengaruhi kepuasan kerja. Hubungan fungsional mencerminkan sejauh mana atasan membantu tenaga kerja untuk memuaskan nilai-nilai perkerjaan yang penting bagi tenaga kerja. Hubungan keseluruhan didasarkan pada keterarikan antar pribadi yang mencerminkan sikap dasar dan nilai-nilai yang serupa. Kelima, rekan kerja. Kepuasan kerja yang ada pada para pekerja timbul karena mereka dalam jumlah tertentu, berada dalam satu ruangan kerja, sehingga mereka dapat saling berbicara (kebutuhan sosial terpenuhi). Sifat alami dari kelompok atau tim kerja, akan mempengaruhi kepuasan kerja. Pada umumnya, rekan kerja atau anggota tim koorporatif merupakan sumber kepuasan kerja yang paling sederhana pada karyawan secara individu. Kelompok kerja bertindak sebagai sumber dukungan, 
kenyamanan, nasihat, dan bantuan kepada anggota individu. Keenam, kondisi kerja. Bekerja dalam ruangan kerja yang sempit, panas, cahaya lampu, kondisi kerja yang tidak mengenakan dan menimbulkan keengganan untuk bekerja. Dalam hal ini perusahaan perlu menyediakan ruang kerja yang terang, dan peralatan kerja yang nyaman untuk digunakan. Dalam kondisi seperti ini, kebutuhankebutuhan fisik yang terpenuhi akan memuaskan tenaga kerja.

Menurut Organ dalam Peng dan Chiu (2010), Organizational Citizenship Behavior adalah salah satu prilaku karyawan yang melebihi peran yang diwajibkan yang secara tidak langsung menguntungkan organisasi dan memberikan dampak yang efektivitas bagi organisasi.Menurut Robbins (2003,p.30) Organization Citizenship Behavior (OCB) adalah perilaku diskresioner yang bukan merupakan bagian dari persyaratan-persyaratan jabatan formal seorang karyawan, meskipun demikian hal itu mempromosikan jabatan formal seseorang karyawan, meskipun demikian hal itu mempromosikan pemfungsian efektif atas organisasi.

Menurut Organ, dkk (2006), OCB terdiri dari lima dimensi sebagai berikut. Altruism, yaitu perilaku membantu meringankan pekerjaan yang ditunjukan kepada individu lain dalam suatu organisasi, misalnya membantu rekan kerja yang tidak sehat. Courtesy, yaitu membantu temen kerja mencegah timbulnya masalah sehubungan dengan pekerjaannya dengan cara memberi konsultasi dan informasi serta menghargai kebutuhan mereka, atau memahami dan berempati walaupun saat dikritik. Sportsmanship, yaitu toleransi pada situasi yang kurang ideal di tempat kerja tanpa mengeluh, misalnya ikut menanggung kegagalan proyek tim mungkin akan berhasil dengan mengikuti nasihat anggota. Civic virtue, yaitu terlibat dalam kegiatan-kegiatan organisasi dan peduli pada kelangsungan hidup organisasi, misalnya rela mewakili perusahaan untuk program bersama. Conscientiousness, yaitu melakukan hal-hal yang menguntungkan organisasi, misalnya mematuhi peraturan-peraturan di organisasi dan bersedia lembur untuk menyesaikan proyek.

\section{METODE PENELITIAN}

Penelitian ini dilakukan dengan analisis kuantitatif dan kualitatif dengan jenis penelitian asosiatif untuk mengetahui pengaruh atau juga hubungan antara dua variabel atau lebih. Metode penelitian dengan survei; data dikumpulkan dengan menyebarkan kuesioner kepada seluruh karyawan pada PT Prima Graphia Digital yaitu 86 responden. Metode analisis yang digunakan dalam penelitian ini adalah regresi sederhana dan regresi berganda untuk mengetahui pengaruh variabel bebas terhadap variabel terikat secara partial dan secara simultan.

\section{HASIL DAN PEMBAHASAN}

Hasil penelitian menunjukan bahwa mayoritas responden dari PT Prima Graphia Digital 57\% adalah pria dan 43\% adalah wanita. Mayoritas responden (86\%) berusia 21-30 tahun dengan tingkat pendidikan SMA/sederajat dan bekerja selama 1-2 tahun di PT Prima Graphia Digital. Tabel 1 menunjukkan hasil analisis korelasi.

Tabel 1 Rangkuman Hasil Analisis Korelasi

\begin{tabular}{lcl}
\hline Hubungan Antara & Korelasi & \multicolumn{1}{c}{ Sifat Hubungan } \\
\hline $\mathrm{X}_{1}$ dengan $\mathrm{Y}$ & 0,547 & Cukup kuat, positif dan signifikan \\
$\mathrm{X}_{2}$ dengan $\mathrm{Y}$ & 0,695 & Kuat, positif dan signifikan \\
$\mathrm{X}_{1}, \mathrm{X}_{2}$ dengan $\mathrm{Y}$ & 0,575 & Cukup kuat, positif dan signifikan \\
\hline
\end{tabular}


Dari Tabel 1 diketahui bahwa semua variabel bebas memiliki hubungan yang cukup kuat dan kuat, positif dan signifikan terhadap variabel terikat yaitu Organizational Citizenship Behavior. Sementara Gambar 1 menunjukkan pengaruh X1, X2 terhadap Y.

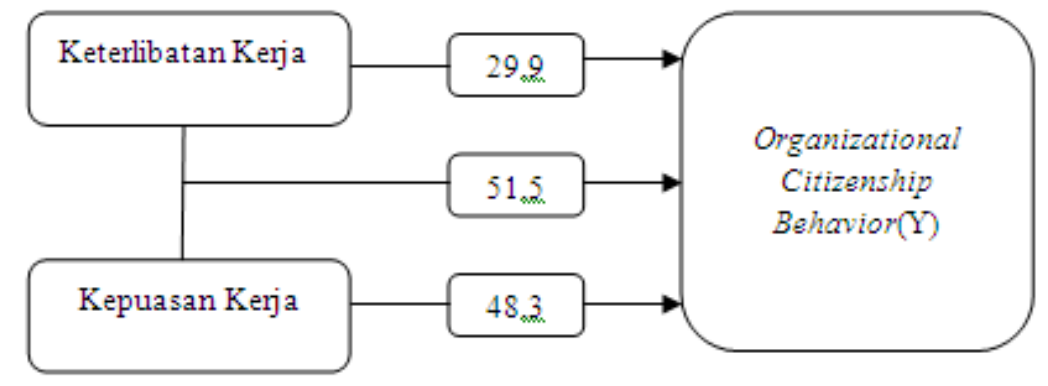

Gambar 1 Pengaruh X1, X2 terhadap Y

Dari hasil penelitian yang dilakukan dapat diketahui sebagai berikut. Pertama, pengaruh keterlibatan kerja (X1) terhadap organizational citizenship behavior (Y) memiliki pengaruh yang signifikan sebesar 29,9\% pada PT Prima Graphia Digital. Sehingga jika karyawan memiliki keterlibatan kerja yang baik, Organizational Citizenship Behavior juga akan meningkat. Begitu juga sebaliknya jika karyawan memiliki keterlibatan kerja yang rendah, organizational citizenship behavior juga akan menurun. Kedua, pengaruh kepuasan kerja (X2) terhadap Organizational Citizenship Behavior (Y) memiliki pengaruh yang signifikan sebesar 48,3\% pada PT Prima Graphia Digital. Sehingga jika kepuasan kerja karyawan tinggi, Organizational Citizenship Behavior akan meningkat. Begitu juga sebaliknya jika kepuasan kerja karyawan rendah, Organizational Citizenship Behavior juga akan menurun. Ketiga, pengaruh keterlibatan kerja (X1) dan kepuasan kerja (X2) secara silmutan terhadap Organizational Citizenship Behavior (Y) memiliki pengaruh yang signifikan sebesar 51,5\% pada PT Prima Graphia Digital. Untuk lebih jelasnya, Tabel 2 berikut menunjukkan hasil pengolahan data.

Tabel 2 Ringkasan Hasil Pengolahan Data

\begin{tabular}{llll}
\multicolumn{1}{c}{ Variabel } & \multicolumn{1}{c}{ Kolerasi } & \multicolumn{1}{c}{ Pengaruh } & \multicolumn{1}{c}{ Persamaan Regresi } \\
\hline X1 --> Y & 0,547 (Cukup Kuat) & $29,9 \%$ & $\mathrm{Y}=1.904+0,363 \mathrm{X} 1$ \\
$\mathrm{X} 2$--> Y & 0,695 (Kuat) & $48,3 \%$ & $\mathrm{Y}=1,352+0,535 \mathrm{X} 2$ \\
$\mathrm{X} 1, \mathrm{X} 2$--> Y & 0,575 (Cukup Kuat) & $51,5 \%$ & $\mathrm{Y}=1,184+0,145 \mathrm{X} 1+0,437 \mathrm{X} 2$ \\
\hline
\end{tabular}

Dari hasil kuesioner yang dilanjutkan dengan wawancara diketahui bahwa dimensi pentingnya pekerjaan bagi individu mendapat respons yang cukup rendah dibandingkan dengan dimensi lainnya. Hal ini disebabkan karyawan merasa pekerjaan mereka cenderung membosankan. Selain itu mereka merasakan otoritas pekerjaan yang sempit dan tidak ada ruang atau media bagi mereka untuk menyalurkan pendapat dan ide. Sehingga bagi karyawan pekerjaan yang saat ini mereka lakukan bukanlah hal yang terpenting. Untuk dimensi lain dari variabel keterlibatan kerja, mayoritas responden menyatakan cukup puas karena kinerja mereka dihargai perusahaan dengan adanya pemberian reward dan bonus sehingga mereka merasakan adanya kebanggaan.

Untuk variabel kepuasan kerja mayoritas responden menyatakan tidak puas untuk dimensi imbalan, terutama untuk indikator pemberian gaji yang adil. Dari wawancara dengan karyawan, diketahui bahwa mereka merasa bahwa pemberian gaji kepada karyawan dirasakan tidak adil karena untuk pekerjaan yang sama, perusahaan memberikan tingkat gaji yang berbeda. Menurut persepsi karyawan, seharusnya untuk pekerjaan yang sama, mereka menerima gaji yang sama. Menurut pihak perusahaan, tingkat gaji yang diberikan kepada karyawan disesuaikan oleh masa kerja dan skill. 
Namun kelihatannya kebijakan ini belum dikomunikasikan dengan baik kepada seluruh karyawan sehingga mereka memiliki prsepsi yang berbeda dan menimbulkan ketidakpuasan kerja. Sedangkan untuk dimensi kesempatan promosi dirasakan cukup baik dan karyawan menyatakan puas karena promosi jabatan dilakukan secara terbuka dan adil berdasarkan kinerja karyawan. Karyawan juga merasa termotivasi dengan adanya kebijakan promosi ini. Dimensi lain dari kepuasan kerja seperti rekan kerja, pengawasan, kondisi kerja, dan pekerjaan itu sendiri dirasakan baik; dan karyawan merasa cukup puas. Atasan dirasakan cukup perhatian dan memberikan pengawasan atas pekerjaan karyawan seperlunya. Karyawan juga merasakan kondisi kerja yang yang nyaman serta adanya rekan kerja yang kooperatif dan dapat diajak untuk bekerja sama.

Variabel OCB yang selama ini dilakukan di perushaan sudah berjalan cukup baik. Hal ini terlihat dari respons karyawan yang baik di hampir semua dimensi, kecuali untuk dimensi conscientoiusness. Hampir semua karyawan menyatakan tidak bersedia dan kurang setuju untuk bekerja lembur karena tidak ada upah lembur dari perusahaan. Menurut pihak perusahaan, kondisi finansial perusahaan yang belum mapan menyebabkan perusahaan tidak mampu memberikan upah lembur kepada karyawan. Namun bagi karyawan, upah lembur merupakan hak mereka yang harus dibayarkan perusahaan setiap kali mereka harus bekerja melebihi jam kerja normal. Oleh karena itu, meskipun karyawan menyadari bahwa lembur tersebut perlu karena banyak pekerjaan yang diterima perusahaan, mereka enggan melakukannya. Dimensi lain menilai karyawan cukup baik sehingga bisa dilihat bahwa karyawan di peprusahaan sudah memiliki OCB yang cukup baik. Misalnya, karyawan secara sukarela terlibat dalam setiap kegiatan perusahaan, bersedia membantu rekan kerja yang lain yang sakit atau memiliki beban kerja berlebih serta lebih toleransi terhadap situasi-situasi yang kurang baik tanpa mengajukan keberatan atau keluhan.

\section{SIMPULAN}

Simpulan yang didapat dari penelitian ini adalah sebagai berikut. Pertama, keterlibatan kerja berkontribusi positif dan signifikan terhadap perilaku Organizational Citizenship Behavior karyawan di PT Prima Graphia Digital. Kedua, kepuasan kerja berkontribusi positif dan signifikan terhadap perilaku Organizational Citizenship Behavior karyawan di PT Prima Graphia Digital. Ketiga, keterlibatan kerja dan kepuasan kerja secara silmutan memiliki pengaruh yang signifikan terhadap Organizational Citizenship Behavior karyawan di PT Prima Graphia Digital.

Dari simpulan, maka hasil penelitian menunjukkan bahwa Kepuasan Kerja merupakan faktor yang paling berpengaruh terhadap Organizational Citizenship Behavior. Sedangkan faktor kedua yang memengaruhi Organizational Citizenship Behavior adalah Keterlibatan Kerja. Sehingga perilaku Organizational Citizenship Behavior akan makin baik jika tingkat kepuasan kerja karyawan tinggi.

\section{Saran}

Berdasarkan hasil penelitian dan pembahasan, maka saran yang dapat diberikan kepada PT Prima Graphia Digital adalah sebagai berikut. Pertama, kepuasan kerja karyawan merupakah salah satu faktor utama yang harus diperhatikan oleh PT Prima Graphia Digital karena faktor tersebut memiliki pengaruh yang besar dalam menerapkan perilaku Organizational Citizenship Behavior. Pemberian gaji yang dirasa karyawan kurang adil menyebabkan karyawan merasa kurang puas. Hal ini harus diperhatikan oleh perusahaan dan perusahaan harus memberikan informasi tentang sistem gaji yang diberikan di perusahaan pada saat karyawan diterima perusahaan, apakah sistem gaji diberikan berdasarkan pendidikan, lama bekerja, memiliki banyak skill, dan sebagainya. Pemberian gaji yang tidak adil dapat memengaruhi semangat dan motivasi karyawan dalam mencapai kepuasan dalam bekerja. 
Faktor kedua yang harus diperhatikan PT Prima Graphia Digital adalah untuk meningkatkan keterlibatan kerja karyawan terhadap pekerjaannya. Karena kondisi finansial yang kurang, diharapkan perusahaan menerapkan manajemen yang lebih terbuka, lebih sering melibatkan karyawan dalam perusahaan dalam pengambilan keputusan serta penyampaian aspirasi, saran atau ide kepada perusahaan. Dengan demikian karyawan akan merasa lebih dihargai dan dianggap sebagai aset dalam perusahaan tersebut.

Ketiga, dalam Organizational Citizenship Behavior, PT Prima Graphia Digital juga harus memerhatikan karyawan yang bekerja lembur. Para karyawan rata-rata menolak untuk bekerja lembur karena mereka merasakan bahwa walaupun mereka bekerja lembur, mereka tidak mendapatkan penghasilan tambahan dari bekerja lembur. Sehingga untuk meminimalkan jam lembur yang tidak diberikan upah lembur karena kondisi finansial perusahaan, perusahaan disarankan untuk menambahkan sumber daya manusia secara outsource yang memiliki bayaran yang lebih rendah. Atau sebaiknya perusahaan menerima oderan yang jumlahnya sesuai dengan kemampuan dan kapasitas sumber daya manusia yang ada di dalam perusahaan.

Keempat, penelitian yang akan datang diharapkan dapat melakukan penelitian terhadap faktorfaktor lain yang memengaruhi Organizational Citizenship Behavior. Kedua faktor yang pada penelitian ini, yaitu Keterlibatan Kerja dan Kepuasan Kerja, terhadap Organizational Citizenship Behavior sebesar 51,5\% dan 48,5\% dipengaruhi oleh faktor lainnya.

\section{DAFTAR PUSTAKA}

Istijanto. (2005). Riset SDM, Cara Praktis Mendekteksi Dimensi-Dimensi Kerja Karyawan. Jakarta: Gramedia Pustaka Utama.

Liao, C. S. and Lee, C. W. (2009). An Empirical Study of Employee Job Involvement and Personality Traits: The Case of Taiwan. Journal of Economics and Management, 3(1), pp. 22-36.

Luthans, F. (2006). Prilaku Organisasi. Edisi Sepuluh. Yogyakarta: ANDI.

Mathis, R. L., and Jackson, J. H. (2006). Human Resource Management. Jakarta: Salemba Empat.

Millmore, Mike, et.al., (2007) Strategic Human Resource Management, Prentice-Hall

Organ, D. W., Podsakoff, P. M., and Mac Kenzie, S. B. (2006). Organizational Citizenship Behavior. Its Nature, Antecendents, and Consequences. California: Sage.

Peng, J. C., and Chiu, S. F. (2010). An Integrative Model Linking Feedback Environment and Organizational Citizenship Behavior. Journal of Social Psychology. 156(6), pp. 582-607.

Robbins Stephen P. (2008). Prilaku Organisasi. Salemba Empat, Jakarta.

Robbins, S. P. (2003). Perilaku Organisasi. Edisi Kesembilan. Jakarta: Indeks.

Robbins, Stephen P., Coulter, Mary. (2007). Manajemen, Edisi Kedelapan. Jakarta: Indeks. 